\title{
Allobacillus salarius sp. nov., and Allobacillus saliphilus sp. nov., Isolated from Shrimp Paste (ka- $p i)$ in Thailand
}

Supalurk Yiamsombut

Chulalongkorn University Faculty of Science

Pawina Kanchanasin

Chulalongkorn University Faculty of Pharmaceutical Sciences

Wongsakorn Phongsopitanun

Chulalongkorn University Faculty of Pharmaceutical Sciences

Nattakorn Kuncharoen

Kasetsart University - Bangkhen Campus: Kasetsart University

Ancharida Savarajara

Chulalongkorn University Faculty of Science

Wenyu Shi

Institute of Microbiology Chinese Academy of Sciences

Linhuan Wu

Institute of Microbiology Chinese Academy of Sciences

Juncai Ma

Institute of Microbiology Chinese Academy of Sciences

Somboon Tanasupawat ( $\nabla$ somboon.t@chula.ac.th )

Faculty of Pharmaceutical Sciences, Chulalongkorn University https://orcid.org/0000-0002-7149-5341

\section{Research Article}

Keywords: Allobacillus salarius, Allobacillus saliphilus, moderately halophile, shrimp paste, spore-forming bacteria

Posted Date: August 13th, 2021

DOl: https://doi.org/10.21203/rs.3.rs-797674/v1

License: (c) (i) This work is licensed under a Creative Commons Attribution 4.0 International License. Read Full License 
Version of Record: A version of this preprint was published at Archives of Microbiology on December 24th, 2021. See the published version at https://doi.org/10.1007/s00203-021-02694-9. 


\section{Abstract}

The moderately halophilic, Gram-stain-positive, spore-forming rods, designated SKP4-8 ${ }^{\top}$ and SKP8-2 ${ }^{\top}$ isolated from a traditional fermented shrimp paste (Ka-pi), were taxonomic studied based on polyphasic approach. Strain SKP4-8 ${ }^{\top}$ grew at $\mathrm{pH}$ 6.0-9.0 (optimum 7.0), at $25-45^{\circ} \mathrm{C}$ (optimum $37^{\circ} \mathrm{C}$ ) and in $1-16 \%$ $(\mathrm{w} / \mathrm{v}) \mathrm{NaCl}$ (optimum 5-10). Strain SKP8-2 ${ }^{\top}$ grew at pH 6.0-9.0 (optimum 8.0 ), at $25-45^{\circ} \mathrm{C}$ (optimum $37^{\circ} \mathrm{C}$ ) and in $0-20 \%(\mathrm{w} / \mathrm{v}) \mathrm{NaCl}$ (optimum 3-10\%). The strains contained meso-diaminopimelic acid in cell-wall peptidoglycan and the major menaquinone was MK-7. Strain SKP4-8 ${ }^{\top}$ contained iso- $C_{15: 0}$, antesio- $C_{15: 0}$ and iso- $\mathrm{C}_{17: 0}$; and strain SKP8-2 ${ }^{\top}$ contained antesio- $\mathrm{C}_{15: 0}$, iso- $\mathrm{C}_{15: 0}$, iso- $\mathrm{C}_{16: 0}$ and antesio- $\mathrm{C}_{17: 0}$ as major cellular fatty acids.Phosphatidylglycerol, diphosphatidylglycerol, unknown phospholipids and an unknown glycolipid were detected as major polar lipids. On the basis of 16S rRNA gene sequence analysis, strains SKP4-8 ${ }^{\top}$ and SKP8 $-2^{\top}$ belonged to the genus Allobacillus and was closely related to Allobacillus halotolerans LMG $24826^{\top}$ with $98.8 \%$ and $99.3 \%$ similarity, respectively. The comparative genome analysis based on average nucleotide identity (ANI) and digital DNA-DNA hybridization revealed that both strains showed the values below 95 and $70 \%$, from each other and the Allobacillus halotolerans LMG $24826^{\top}$, respectively. Based on data from this polyphasic study, strains SKP4-8 ${ }^{\top}$ and SKP8-2 ${ }^{\top}$ represent the novel species of the genus Allobacillus and the name Allobacillus salarius sp. nov. was proposed for SKP4-

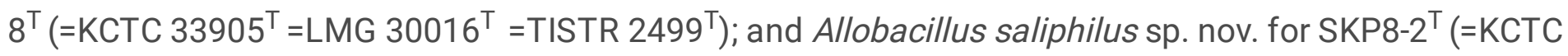

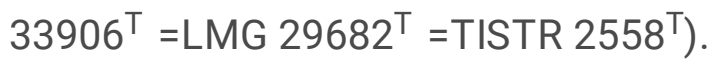

\section{Introduction}

Shrimp paste, a dark brown, gray or pink brown traditionally called Ka-pi is a strong-smelling commonly used as a cooking ingredient. It is produced by fermentation of shrimp with salt for 1-3 months and has rich in various nutrients, particularly amino acids and peptides, and contains a high concentration of $\mathrm{NaCl}$ (Phithakpol et al. 1995; Tanasupawat and Komagata 2001). Moderately halophilic rod-shaped, have been isolated from shrimp paste and was proposed as the new genus Allobacillus (Sheu et al. 2011). To date, the numerous reports on moderately halophilic bacteria have revealed novel isolates with distinct properties from various salty environments in the member of genera including Alkalibacillus (Jeon et al. 2005), Bacillus (Ventosa et al. 1989), Gracilibacillus (Wainø et al. 1999), Halobacillus (Spring et al. 1996), Lentibacillus (Yoon et al. 2002), Marinococcus (Hao et al. 1984), Piscibacillus (Tanasupawat et al. 2007), Thalassobacillus (García et al. 2005) and Virgibacillus (Heyndrickx et al. 1998). Many species were isolated from fermented foods such as Gracilibacillus thailandensis (Chamroensaksri et al. 2010), Lentibacillus kapialis (Pakdeeto et al. 2007a), Lentibacillus salicampi and Lentibacillus juripiscarius (Namwong et al. 2005), Oceanobacillus kapialis (Namwong et al. 2009), Piscibacillus salipiscarius (Tanasupawat et al. 2007), Salinicoccus siamensis (Pakdeeto et al. 2007b), Virgibacillus kapii (Daroonpunt et al. 2016) and Virgibacillus siamensis (Tanasupawat et al. 2010). This study, a strain SKP8-2 ${ }^{\top}$ was isolated from shrimp paste ( $k a-p i)$ in Thailand and found to represent the novel species of the genus Allobacillus and was subsequently evaluated by the means of a polyphasic taxonomy. 


\section{Materials And Methods}

\section{Bacterial isolation}

Strains SKP4-8 ${ }^{\top}$ and SKP8 $-2^{\top}$ were isolated from shrimp paste collected from the market in Samut Sakhon province, Thailand by using spread-plate technique duplicate on modified JCM medium no.377 agar plates, contained (g/L): $5 \mathrm{~g}$ casamino acids, $5 \mathrm{~g}$ yeast extract, $1 \mathrm{~g}$ sodium glutamate, $3 \mathrm{~g}$ trisodium citrate, $20 \mathrm{~g}$ $\mathrm{MgSO}_{4} \otimes 7 \mathrm{H}_{2} \mathrm{O}, 2 \mathrm{~g} \mathrm{KCl}, 50 \mathrm{~g} \mathrm{NaCl}, 0.036 \mathrm{~g} \mathrm{FeCl}_{2} \varangle 4 \mathrm{H}_{2} \mathrm{O}, 0.0036 \mathrm{~g} \mathrm{MnCl}_{2} \varangle 4 \mathrm{H}_{2} \mathrm{O}, 20 \mathrm{~g}$ agar (pH adjusted to 7.07.2) and incubated at $37^{\circ} \mathrm{C}$ for $3-7$ days.

\section{Phenotypic characteristics}

The colonies with different cell size, cell shape, and color were examined on the cell grown on modified JCM medium no. 377 agar at $37^{\circ} \mathrm{C}$ after 3 days. The Hucker-Conn modification was used for Gram staining (Hucker and Conn 1923). Cell form and spore formation were observed under the light microscope (CH-2, Olympus) and electron microscope (JSM-5410LV, Japan). Flagella were examined as described by Forbes (1981). Anaerobic growth was tested by incubating the cultures on modified JCM medium no. 377 plates in an anaerobic jar with AnaeroPack-Anaero (Mitsubishi Gas Chemical, MGC). Catalase and oxidase activities and nitrate reduction were determined as described by Barrow and Feltham (Barrow and Feltham 1993). Hydrolysis of aesculin, gelatin, starch, skim milk and Tween 20, Tween 40, Tween 60 and Tween 80 were determined as described by Namwong et al. (2005). Arginine hydrolysis was performed by using the medium reported by Thornley (Thornley 1960). Acid production from carbohydrate was determined in the use of basal medium composed $(\mathrm{g} / \mathrm{L})$ : of $5 \mathrm{~g}$ carbohydrate, $1 \mathrm{~g}$ casamino acids, $0.1 \mathrm{~g}$ yeast extract, $1 \mathrm{~g}$ sodium glutamate, $3 \mathrm{~g}$ trisodium citrate, $20 \mathrm{~g} \mathrm{MgSO}_{4} \otimes 7 \mathrm{H}_{2} \mathrm{O}, 2 \mathrm{~g} \mathrm{KCl}, 50 \mathrm{~g} \mathrm{NaCl}, 0.036 \mathrm{~g} \mathrm{FeCl}_{2} \otimes 4 \mathrm{H}_{2} \mathrm{O}, 0.0036$ $\mathrm{g} \mathrm{MnCl}_{2} \varangle 4 \mathrm{H}_{2} \mathrm{O}$ and was adjusted to $\mathrm{pH} 7.0$ and incubated at $37^{\circ} \mathrm{C}$ for 7 days. Phenol red was used as an indicator. Effects of growth at various $\mathrm{NaCl}$ concentrations were investigated in modified JCM medium no. 377 broth omitting the $\mathrm{MgSO}_{4} \otimes 7 \mathrm{H}_{2} \mathrm{O}$ with different concentrations of $\mathrm{NaCl}(0$ and $1-20 \%, w / v$ with an interval of 1). Growth at different pH (4 to 10) was investigated in buffer medium (Sorokin 2005) and growth at different temperatures $\left(10-50^{\circ} \mathrm{C}\right)$ was investigated on modified JCM medium no. 377 agar plates. Antibiotic susceptibility was examined by disc diffusion assay (Acar and Goldstein 1991) on MuellerHinton agar (Difco) supplemented with $5 \%(\mathrm{w} / \mathrm{v}) \mathrm{NaCl}$. The enzyme activities were determined using API ZYM system (bioMérieux), according to the manufacturer's instructions. All tests were carried out in media supplemented with $5 \% \mathrm{NaCl}$, except for the investigation of effects of growth at various $\mathrm{NaCl}$ concentrations.

\section{Chemotaxonomy}

The cell biomass for chemotaxonomic characterization was produced in modified JCM medium no. 377 at $30^{\circ} \mathrm{C}$ for 3 days. Diaminopimelic acid in the cell wall and menaquinone component were determined as described by Komagata and Suzuki (1987). Polar lipids were extracted and analyzed by using the procedure of as described by Minnikin et al. 1984 and identified by two-dimensional TLC followed by spraying with appropriate detection reagents (Komagata and Suzuki 1987). For quantitative analysis of 
cellular fatty acid compositions, cells were cultivated on modified JCM medium no. 377 agar plates at $30^{\circ} \mathrm{C}$ for $48 \mathrm{~h}$. Fatty acid methyl esters (FAMEs) were prepared and identified according to the instructions of the Microbial Identification System (MIDI) (Sasser 1990).

\section{Genotypic and phylogenetic analysis}

Chromosomal DNA was isolated and purified from cells grown in modified JCM medium no. 377 according to the method of Saito and Miura (Saito and Miura 1963). The 16S rRNA gene was amplified, purified, and sequenced as described by Namwong et al. (2005). The sequence determined was aligned with selected sequences obtained from the GenBank/EMBL/DDBJ database employing CLUSTAL_X version 1.83 (Thompson et al. 1997). The alignment was manually edited, and positions with gaps and ambiguous bases were eliminated prior to construction of a phylogenetic tree. The phylogenetic trees based on the neighbor-joining method (Saitou and Nei 1987) and the maximum-likelihood method (Felsenstein 1981) were constructed in MEGA version 6 (Tamura et al. 2013). The confidence values of branches of the phylogenetic tree were determined using bootstrap analyses (Felsenstein 1985) based on 1,000 resamplings.

Whole genome sequence of strain SKP4-8 ${ }^{\top}$, SKP8-2 ${ }^{\top}$ and Allobacillus halotolerans LMG $24826^{\top}$ were performed using an Illumina Miseq platform (Illumina, Inc., San Diego, US-CA) by the World Data Center for Microorganisms (WDCM) under the Globa Catalogue of Microorganisms (GCM) 2.0 project. Assembling the reads to contigs were accomplished by using SPAdes 3.12 (Bankevich et al. 2012). The assembled genome of strain SKP4-8 ${ }^{\top}$, SKP8-2 ${ }^{\top}$ and Allobacillus halotolerans $L M G ~ 24826^{\top}$ are available public on the GenBank (accession numbers: VMHE00000000, JAGSIE000000000 and JAHLZF000000000). The genome was annotated by using the DFAST sever (Tanizawa et al. 2018) followed the NCBI Prokaryotic Genome Annotation Pipeline (PGAP). Average nucleotide identity (ANI) values were calculated with pairwise genome alignment of the draft genome sequences of Allobacillus halotolerans LMG $24826^{\top}$ (JAHLZF000000000) by using the ANI-BLAST (ANIb) and ANI-MUMmer (ANIm) algorithms (Meier-Kolthoff and Göker 2019) implemented within the JspeciesWS web service (Richter and Rosselló-Móra 2009). Calculation of the digital DNA-DNA hybridization (dDDH) values was achieved by using the Genome-to-Genome Distance Calculator (GGDC 2.1) using the BLAST+ method (Richter et al. 2016). Results were based on the recommended formula 2 (identities/HSP length), which is useful when dealing with incomplete draft genomes.

\section{Results And Discussion}

Strains SKP4-8 ${ }^{\top}$ and SKP8-2 ${ }^{\top}$ were Gram-stain-positive, strictly aerobic and spore-forming rods.

Endospores are produced at terminal position in swollen sporangia (Supplementary Fig. S1). Colonies were smooth, circular, low convex and cream in the color (1-2 $\mathrm{mm}$ in dimeter) after grew on modified JCM medium no. 377 agar at $37^{\circ} \mathrm{C}$ for 2 days. Motile by peritrichous flagella. No growth in anaerobic condition. Strain SKP4-8 $8^{\top}$ grew in $1-16 \%(\mathrm{w} / \mathrm{v}) \mathrm{NaCl}$ (optimum $5-10 \%$ ), at $25-45^{\circ} \mathrm{C}$ (optimum $37^{\circ} \mathrm{C}$ ) and at $\mathrm{pH} 6.0-$ 9.0 (optimum 7.0). Strain SKP8- ${ }^{\top}$ grew in $0-20 \%(w / v) ~ N a C l ~(o p t i m u m ~ 3-10 \%), ~ a t ~ 25-45^{\circ} \mathrm{C}$ (optimum 
$37^{\circ} \mathrm{C}$ ) and at $\mathrm{pH} 6.0-9.0$ (optimum 8.0). The results of phenotypic characteristics are given in the species description and listed in Table 1. The strains SKP4-8 ${ }^{\top}$ and SKP8-2 ${ }^{\top}$ were sensitive to chloramphenicol (30 $\mu \mathrm{g})$, gentamicin $(10 \mu \mathrm{g})$, kanamycin $(30 \mu \mathrm{g})$, novobiocin $(5 \mu \mathrm{g})$, penicillin $\mathrm{G}(20 \mathrm{U})$, rifampicin $(5 \mu \mathrm{g})$ and tetracycline $(30 \mu \mathrm{g})$ but were resistant to ampicillin $(10 \mu \mathrm{g})$ and streptomycin $(10 \mu \mathrm{g})$.

Table 1

Differential characteristics of strains SKP4-8 ${ }^{\top}$, SKP8-2 and Allobacillus halotolerans LMG $24826^{\top}$. All data are from this study. + , positive reaction; -, negative reaction.

\begin{tabular}{|llll|}
\hline Characteristics & SKP4-8 $^{\text {T }}$ & SKP8-2 $^{\text {T }}$ & LMG 24826 $^{\text {T }}$ \\
\hline Temperature range for growth (optimum) $\left({ }^{\circ} \mathrm{C}\right)$ & $25-45(37)$ & $25-45(37)$ & $20-45(37)$ \\
\hline NaCl range for growth (optimum) \% (w/v) & $1-16(5-10)$ & $0-20(3-10)$ & $1-20(5-10)$ \\
\hline Nitrate reduction & + & + & - \\
\hline Hydrolysis of Tween 80 & + & - & - \\
\hline API ZYM tests & & & - \\
\hline C14 Lipase & + & - & - \\
\hline Trypsin & + & - & - \\
\hline Acid phosphatase & + & + & - \\
\hline Acid production from: & & & - \\
\hline D-Fructose & - & + & + \\
\hline D-Galactose & & + & \\
\hline D-Mannose & - & - & \\
\hline D-Ribose & - & & + \\
\hline
\end{tabular}

Strain SKP4-8 ${ }^{\top}$ and SKP8- ${ }^{\top}$ contained meso-diaminopimelic acid in the cell wall peptidoglycan and the major menaquinone was MK-7. The major fatty acids found in strain SKP4-8 ${ }^{\top}$ were iso- $\mathrm{C}_{15: 0}(54.4 \%)$, antesio- $\mathrm{C}_{15: 0}(11.9 \%)$, and iso- $\mathrm{C}_{17: 0}(11.6 \%)$. In addition, the other fatty acids, $\mathrm{C}_{16: 0}(0.8 \%)$, iso- $\mathrm{C}_{14: 0}(1.8$ $\%)$, iso- $\mathrm{C}_{16: 0}(3.2 \%)$, anteiso- $\mathrm{C}_{17: 0}(4.5 \%), \mathrm{C}_{16: 1} \omega 11 \mathrm{c}(0.6 \%) \mathrm{C}_{16: 1} \omega 7 \mathrm{c}$ alcohol $(5.7 \%)$ and summed feature $4(1.7 \%)$ were also detected and are different from strain SKP8- ${ }^{\top}$ (Table 2). The major fatty acids found in strain SKP8- ${ }^{\top}$ contained antesio- $\mathrm{C}_{15: 0}(36.3 \%)$, iso- $\mathrm{C}_{15: 0}(19.2 \%)$, iso- $\mathrm{C}_{16: 0}(16.5 \%)$ and antesio- $\mathrm{C}_{17: 0}(16.3$ $\%)$. In addition, the other fatty acids, $\mathrm{C}_{16: 0}(0.7 \%)$, iso- $\mathrm{C}_{14: 0}(4.4 \%)$, iso- $\mathrm{C}_{17: 0}(3.2 \%), \mathrm{C}_{16: 1} \omega 7 \mathrm{c}$ alcohol (1.4 $\%$ ) and summed feature $4(0.6 \%)$ were also detected (Table 2). The polar lipids of strain SKP4-8 ${ }^{\top}$ were phosphotidylglycerol (PG), diphosphatidylglycerol (DPG), three unknown phospholipids (PL1, PL2 and PL3) and unknown glycolipid (GL) (Supplementary Fig. S2). Strain SKP8-2 ${ }^{\top}$ showed major polar lipid similar to 
strain SKP4-8 ${ }^{\top}$ which contained of PG, DPG, unknown glycolipid (GL), but showed two unknown phospholipids (PL1 and PL2) (Supplementary Fig. S3).

Table 2

Cellular fatty acids composition (\%) of strains SKP4-8 ${ }^{\top}$, SKP $^{-}-^{\top}$ and A. halotolerans LMG $24826^{\top}$. Data are determined in this study.

\begin{tabular}{|c|c|c|c|}
\hline Fatty acids & SKP4-8 ${ }^{\top}$ & SKP8-2 ${ }^{\top}$ & LMG $24826^{\top}$ \\
\hline \multicolumn{4}{|c|}{ Saturated straight-chain } \\
\hline$C_{16: 0}$ & 0.8 & 0.7 & 0.7 \\
\hline \multicolumn{4}{|c|}{ Saturated branched-chain } \\
\hline iso- $\mathrm{C}_{14: 0}$ & 1.8 & 4.4 & 5.7 \\
\hline iso- $\mathrm{C}_{15: 0}$ & 54.4 & 19.2 & 5.2 \\
\hline anteiso- $\mathrm{C}_{15: 0}$ & 11.9 & 36.3 & 52.4 \\
\hline iso- $\mathrm{C}_{16: 0}$ & 3.2 & 16.5 & 21.0 \\
\hline iso- $\mathrm{C}_{17: 0}$ & 11.6 & 3.2 & 0.4 \\
\hline anteiso- $\mathrm{C}_{17: 0}$ & 4.5 & 16.3 & 12.1 \\
\hline \multicolumn{4}{|c|}{ Unsaturated straight-chain } \\
\hline $\mathrm{C}_{16: 1} \omega 11 \mathrm{c}$ & 0.6 & - & - \\
\hline $\mathrm{C}_{16: 1} \omega 7 \mathrm{c}$ alcohol & 5.7 & 1.4 & 0.8 \\
\hline Summed Feature 4 & 1.7 & 0.6 & 0.1 \\
\hline \multicolumn{4}{|c|}{ Fatty acids comprising less than $0.5 \%$ are omitted. -, not detected. } \\
\hline Summed feature 4 & . & s & so- $C_{17: 1} B$. \\
\hline
\end{tabular}

The draft genome sequence of strain SKP4-8 ${ }^{\top}$ was $2.59 \mathrm{Mb}$ in size with an average in silico DNA G + C content of $38.8 \mathrm{~mol} \%$. The draft genome sequence of strain SKP8 $-2^{\top}$ was $2.54 \mathrm{Mb}$ in size with an average in silico DNA G + C content of 39.0 mol\%. The draft genomic features of the strains SKP4-8 ${ }^{\top}$ and SKP8- ${ }^{\top}$ are described in Table 3. The ANIb and ANIm values of the draft genomes between strain SKP4-8 ${ }^{\top}$ and its closest related species, $A$. halotolerans LMG $24826^{\top}$ ( 86.6 and $88.1 \%$, respectively) are shown in Table 4 . The ANIb and ANIm values of the draft genomes between strain SKP8- ${ }^{\top}$ and its closest related species, $A$. halotolerans LMG $24826^{\top}$ (87.1 and $88.3 \%$, respectively) are shown in Table 4. Strain SKP4-8 ${ }^{\top}$ exhibited 93.2 and $93.8 \%$ of ANIb and ANIm with SKP8-2 ${ }^{\top}$. Both ANI values are clearly lower than the $95-96 \%$ cut- 
off for species delineation (Meier-Kolthoff et al. 2013). The digital DNA-DNA hybridization (dDDH) value between the genomes of strain SKP4-8 ${ }^{\top}$ and A. halotolerans LMG $24826^{\top}$ was $32.5 \%$ (C.I. model $30.1-$ $35.1 \%)$. The digital DNA-DNA hybridization $(\mathrm{dDDH})$ values between the genomes of the strain SKP8- ${ }^{\top}$ and A. halotolerans LMG $24826^{\top}$ were $33.0 \%$ (C.I. model 30.6-35.5\%) which are significantly lower than the threshold value of $70 \%$ commonly used to delineate separated species status (Richter and Rosselló-Móra 2009) (Table 4), which are significantly lower than the threshold value of $70 \%$ commonly used to delineate separated species status (Wayne et al. 1987). It is concluded from the above results that strains SKP4-8 ${ }^{\top}$ and SKP8-2 ${ }^{\top}$ should be recognized as a new species within the genus Allobacillus.

Table 3

Genomic statistics of strains SKP4-8 ${ }^{\top}$ (VMHE00000000), SKP8-2 ${ }^{\top}$ (JAGSIE000000000) and A. halotolerans LMG $24826^{\top}$ (JAHLZF000000000)

\begin{tabular}{|llll|}
\hline Attribute & SKP4-8 $^{{ }^{\top}}$ & SKP8-2 $^{\boldsymbol{T}}$ & LMG 24826 $^{{ }^{\top}}$ \\
\hline Genome size (bp) & $2,595,246$ & $2,543,747$ & $2,726,708$ \\
\hline G + C content (mol\%) & 38.8 & 39.0 & 39.5 \\
\hline Number of contigs & 102 & 80 & 96 \\
\hline Total genes & 2,666 & 2,622 & 2,820 \\
\hline Number of coding sequences & 2,603 & 2,563 & 2,759 \\
\hline RNA genes & 63 & 59 & 61 \\
\hline
\end{tabular}

Table 4

ANIb and ANIm values (\%) and the digital (in silico) DNA-DNA hybridization (dDDH) values between the draft genomes of strains SKP4-8 ${ }^{\top}$, SKP8- ${ }^{\top}$ and its closely related type strains.

\begin{tabular}{|c|c|c|c|c|c|c|c|c|}
\hline $\begin{array}{l}\text { Query } \\
\text { genome }\end{array}$ & $\begin{array}{l}\text { Reference } \\
\text { genome }\end{array}$ & ANlb & ANIm & $\begin{array}{l}\% \text { dDDH } \\
\text { (Formula } \\
2^{*} \text { ) }\end{array}$ & $\begin{array}{l}\text { Model } \\
\text { C.I. }\end{array}$ & Distance & $\begin{array}{l}\text { Prob. Digital } \\
\text { DNA-DNA } \\
\text { hybridization } \\
\geq 70 \%\end{array}$ & $\begin{array}{l}\mathrm{G}+\mathrm{C} \\
\text { difference }\end{array}$ \\
\hline 1 & 2 & 93.2 & 93.8 & 53.2 & $\begin{array}{l}{[50.5-} \\
55.9 \%]\end{array}$ & 0.0 & 28.9 & 0.1 \\
\hline 1 & 3 & 86.6 & 88.1 & 32.5 & $\begin{array}{l}{[30.1-} \\
35.1 \%]\end{array}$ & 0.1 & 0.2 & 0.7 \\
\hline 2 & 3 & 87.1 & 88.3 & 33.0 & $\begin{array}{l}{[30.6-} \\
35.5 \%]\end{array}$ & 0.1 & 0.3 & 0.5 \\
\hline
\end{tabular}

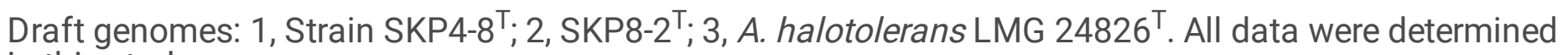
in this study.

*Recommended formula (identities/HSP length), which is liberated of genome length and is thus prosperous against the use of incomplete draft genome 
On the basis of $16 \mathrm{~S}$ rRNA gene sequence analysis, strains SKP4-8 ${ }^{\top}(1471 \mathrm{nt})$ and SKP8-2 ${ }^{\top}(1441 \mathrm{nt})$ were closely related to A. halotolerans LMG $24826^{\top}$ with 98.8 and $99.3 \%$, respectively (Fig. 1, Figs.S4 and S5). Strains SKP4-8 ${ }^{\top}$ exhibited $99.5 \%$ 16S rRNA gene sequence similarity with SKP8- ${ }^{\top}$. In addition, strains SKP4-8 ${ }^{\top}$ and SKP8-2 ${ }^{\top}$ were differentiated from A. halotolerans $\mathrm{LMG} 24628^{\top}$ by growth in $\mathrm{NaCl}$, nitrate reduction, aesculin hydrolysis, and acid production from D-fructose, D-galactose, D-glucose and Dmannose (Table 1), the amount of fatty acids of iso- $\mathrm{C}_{15: 0}$ and anteiso- $\mathrm{C}_{15: 0}$ (Table 2 ) and DNA-DNA relatedness. Strain SKP4-8 ${ }^{\top}$ and SKP8- ${ }^{\top}$ should represent the novel species of the genus Allobacillus for which the name Allobacillus salarius sp. nov. and Allobacillus saliphilus sp. nov. respectively, are proposed.

\section{Description of Allobacillus salarius sp. nov.}

Allobacillus salarius (sa.la'ri.us. L. fem. adj. salarius of, or belonging to salt).

Cells are strictly aerobic Gram-stain-positive rods $(0.25-0.30 \times 0.8-3.5 \mu \mathrm{m})$. Motile by peritrichous flagella. Spores with oval shape are located at terminal position. Colonies are circular, convex, entire and cream in color (1-2 mm in diameter). Growth occurs at $25-45^{\circ} \mathrm{C}, \mathrm{pH} 6.0-9.0$ and $1-16 \%(\mathrm{w} / \mathrm{v}) \mathrm{NaCl}$ (optimally at $37^{\circ} \mathrm{C}$, at pH 7.0 and in $5-10 \% \mathrm{NaCl}$ ). Positive for oxidase, catalase, urease and hydrolysis of aesculin, Tween 20, Tween 40, Tween 60, and Tween 80 . Negative for nitrate reduction and hydrolysis of arginine, gelatin, skim milk, starch and acid production from L-arabinose, D-cellobiose, D-fructose, D-galactose, Dglucose, lactose, maltose, D-mannitol, D-mannose, D-melibiose, D-raffinose, L-rhamnose, D-ribose, D-salicin, D-trehalose and D-xylose. In the API ZYM system positive reaction for alkaline phosphatase, C4 esterase, C8 esterase, C14 lipase, leucine arylamidase, valine arylamidase, cysteine arylamidase, trypsin, $\alpha$ chymotrypsin, acid phosphatase,naphthol-AS-BI-phosphohydrolase, while $\alpha$-galactosidase, $\beta$-galactosidase, $\beta$-glucuronidase, $\alpha$-glucosidase, $\beta$-glucosidase, $N$-acertyl- $\beta$-glucosaminidase, $\alpha$-mannosidase and $\alpha$ fucosidase. The polar lipid profile contains phosphotidylglycerol, diphosphatidylglycerol, three unknown phospholipids and one glycolipids. Contains meso-diaminopimelic acid in the peptidoglycan. The major cellular fatty acids are iso- $\mathrm{C}_{15: 0}$, antesio- $\mathrm{C}_{15: 0}$, and iso- $\mathrm{C}_{17: 0}$ and the major isoprenoid quinone is MK-7.

The type strain is SKP4-8 ${ }^{\top}\left(=\right.$ KCTC $33905^{\top}=$ LMG $30016^{\top}=$ TISTR $\left.2499^{\top}\right)$, isolated from shrimp paste $($ Kapi) collected from a market in Samut Sakhon province, Thailand. The in silico DNA G + C content of the type strain is $38.8 \mathrm{~mol} \%$. The DDBJ accession numbers for the $16 \mathrm{~S}$ rRNA gene sequence of strains SKP4-8 ${ }^{\top}$ is LC215448. The GenBank accession numbers of the draft genome of strain SKP4-8 ${ }^{\top}$ is VMHE00000000.

Description of Allobacillus saliphilus sp. nov.

Allobacillus saliphilus (sa.li.philus.L. n. sal, salis salt; Gr. adj. philos loving; N.L. masc. adj. saliphilus saltloving)

Cells are strictly aerobic Gram-stain-positive, rods $(0.2-0.3 \times 0.6-4.9 \mu \mathrm{m})$. Motiles by peritrichous flagella. Colonies are convex, circular, entire and cream in color (1-2 $\mathrm{mm}$ in diameter). Spores with oval shape are 
located at terminal position. Growth occurs at $25-45^{\circ} \mathrm{C}$ (optimum $37^{\circ} \mathrm{C}$ ), $\mathrm{pH} 6.0-9.0$ (optimum 8) and 0-20 $\%(\mathrm{w} / \mathrm{v}) \mathrm{NaCl}$ (optimum 3-10\% $\mathrm{NaCl}$ ). Positive for oxidase, catalase, nitrate reduction and hydrolysis of aesculin, Tween 20, Tween 40, Tween 60 and urea, but are negative for hydrolysis of arginine, gelatin, skim milk, starch, and Tween 80. Produces acid from D-fructose, D-galactose, D-glucose, D-mannose and sucrose but no acid from L-arabinose, D-cellobiose, lactose, maltose, D-mannitol, D-melibiose, D-raffinose, L-rhamnose, D-ribose, D-salicin, sorbitol, D-trehalose and D-xylose. In the API ZYM system, acid phosphatase, $N$-acetyl- $\beta$-glucosaminidase, alkaline phosphatase, cystine arylamidase, a-galactosidase and a-glucosidase ( $w$ ) are positive while a-chymotrypsin, esterase lipase (C 4), esterase lipase (C 8), afucosidase, $\beta$-galactosidase, $\beta$-glucosidase, $\beta$-glucuronidase, leucine arylamidase, lipase (C14), amannosidase, naphthol-AS-BI-phosphohydrolase, trypsin and valine arylamidase are negative. The polar lipid profile contains phosphotidylglycerol, diphosphatidylglycerol, two unknown phospholipids and an unknown glycolipid. Meso-diaminopimelic acid is presented in the cell wall peptidoglycan. The major cellular fatty acids are antesio- $\mathrm{C}_{15: 0}$, iso- $\mathrm{C}_{15: 0}$, iso- $\mathrm{C}_{16: 0}$ and antesio- $\mathrm{C}_{17: 0}$. The major isoprenoid quinone is MK-7.

The type strain is SKP8-2 ${ }^{\top}\left(=\right.$ KCTC $33906^{\top}=$ LMG $29682^{\top}=$ TISTR $\left.2558^{\top}\right)$, isolated from shrimp paste $(K a-$ pi) collected from a market in Samut Sakhon province, Thailand. The in silico DNA G + C content of the type strain is $39.0 \mathrm{~mol} \%$. The DDBJ accession numbers for the $16 \mathrm{~S}$ rRNA gene sequence of strains SKP8- ${ }^{\top}$ is LC215449. The GenBank accession numbers of the draft genome of strain SKP8-2 ${ }^{\top}$ is JAGSIE000000000.

\section{Declarations}

Funding This study was supported by the Grant for International Research Integration: Research Pyramid, Ratchadaphiseksomphot Endowment Fund (GCURP_58_01_33_01), Chulalongkorn University and the International Partnership Program of Chinese Academy of Sciences (Grant No. 153211 KYSB 201900211). Additional thanks to the Ratchadapiseksomphot Endowment Fund, Chulalongkorn University for a postdoctoral fellowship to P. K.

\section{Compliance with ethical standards}

Conflicts of interest The authors declare that there are no conflicts of interest.

\section{References}

1. Acar JF, Goldstein FW (1991) Disk susceptibility testing. In: Lorian V (ed). Antibiotics in Laboratory Medicine $3^{\text {rd }}$ ed. Baltimore, MD: Williams and Wilkins. pp. 17-52

2. Bankevich A, Nurk S, Antipov D, Gurevich AA, Dvorkin M, Kulikov AS, Lesin VM, Nikolenko SI, Pham S, Prjibelski AD, Pyshkin AV, Sirotkin AV, Vyahhi N, Tesler G, Alekseyev MA, Pevzner PA (2012) SPAdes: a new genome assembly algorithm and its applications to single-cell sequencing. J Comput Biol 19:455477 
3. Barrow GI, Feltham RKA (1993) Cowan and Steel's Manual for the Identification of Medical Bacteria. Cambridge: Cambridge University Press

4. Chamroensaksri N, Tanasupawat S, Akaracharanya A, Visessanguan W, Kudo T, Itoh T (2010) Gracilibacillus thailandensis sp. nov., from fermented fish (pla-ra). Int J Syst Evol Microbiol 60:944-948

5. Daroonpunt R, Tanasupawat S, Kudo T, Ohkuma M, Itoh T (2016) Virgibacillus kapii sp. nov., isolated from Thai shrimp paste (Ka-pi). Int J Syst Evol Microbiol 66:1832-1837

6. Felsenstein J (1981) Evolutionary trees from DNA sequences: a maximum likelihood approach. J Mol Evol 17:368-376

7. Felsenstein J (1985) Confidence limits on phylogenies: An approach using the bootstrap. Evolution 39:783-791

8. Forbes L (1981) Rapid flagella stain. J Clin Microbiol 13:807-809

9. García MT, Gallego V, Ventosa V, Mellado E (2005) Thalassobacillus devorans gen. nov., sp. nov., a moderately halophilic, phenol-degrading, Gram-positive bacterium. Int J Syst Evol Microbiol 55:17891795

10. Hao MV, Kocur M, Komagata K (1984) Marinococcus gen. nov., a new genus for motile cocci with meso-diaminopimelic acid in thecell wall; and Marinococcus albus sp. nov. and Marinococcus halophilus (Novitsky and Kushner) comb. nov. J Gen Appl Microbiol 30:449-459

11. Heyndrickx M, Lebbe L, Kerster K, De Vos P, Forsyth C, Logan N (1998) Virgibacillus: a new genus to accommodate Bacillus panthothenticus (Proom and Knight 1995). Emended description of Virgibacillus panthothenticus. Int J Syst Bacteriol 48:99-106

12. Hucker GJ, Conn HJ (1923) Method of gram staining. Tech Bull N Y St Agric Exp Stn 93:3-37

13. Jeon CO, Lim JM, Lee JM, Xu LH, Jiang CL, Kim CJ (2005) Reclassification of Bacillus haloalkaliphilus Fritze 1996 as Alkalibacillus haloalkaliphilus gen. nov., comb. nov. and the description of Alkalibacillus salilacus sp. nov., a novel halophilic bacterium isolated from a salt lake in China. Int J Syst Evol Microbiol 55:1891-1896

14. Komagata K, Suzuki K (1987) Lipid and cell-wall analysis in bacterial systematics. Methods Microbiol 19:161-203

15. Meier-Kolthoff JP, Auch AF, Klenk HP, Göker M (2013) Genome sequence-based species delimitation with confidence intervals and improved distance functions. BMC Bioinformatics 14:60

16. Meier-Kolthoff JP, Göker M (2019) TYGS is an automated high-throughput platform for state-of-the-art genome-based taxonomy. Nat Commun 10:2182

17. Minnikin DE, O’Donnell AG, Goodfellow M, Alderson G, Athalye M, Schaal A, Parlett JH (1984) An integrated procedure for the extraction of bacterial isoprenoid quinones and polar lipids. J Microbiol Methods 2:233-241

18. Namwong S, Tanasupawat S, Lee KC, Lee JS (2009) Oceanobacillus kapialis sp. nov., from fermented shrimp paste in Thailand. Int J Syst Evol Microbiol 59:2254-2259

19. Namwong S, Tanasupawat S, Smitinont T, Visessanguan W, Kudo T, Itoh T (2005) Isolation of Lentibacillus salicampi strains and Lentibacillus juripiscarius sp. nov. from fish sauce in Thailand. Int 
J Syst Evol Microbiol 55:315-320

20. Pakdeeto A, Tanasupawat S, Thawai C, Moonmangmee S, Kudo T, Itoh T (2007a) Lentibacillus kapialis sp. nov., from fermented shrimp paste in Thailand. Int J Syst Evol Microbiol 57:364-369

21. Pakdeeto A, Tanasupawat S, Thawai C, Moonmangmee S, Kudo T, Itoh T (2007b) Salinicoccus siamensis sp.nov., isolated from fermented shrimp paste in Thailand. Int J Syst Evol Microbiol 57:2004-2008

22. Phithakpol B, Varanyanond W, Reungmaneepaitoon S, Wood H (1995) The Traditional Fermented Foods of Thailand. ASEAN Food Handling Bureau Level, Kuala Lumpur, Malaysia

23. Richter M, Rosselló-Móra R (2019) Shifting the genomic gold standard for the prokaryotic species definition. Proc Natl Acad Sci USA 106:19126-19131

24. Richter M, Rosselló-Móra R, Oliver Glöckner F, Peplies J (2016) JSpeciesWS: a web server for prokaryotic species circumscription based on pairwise genome comparison. Bioinformatics 32:929931

25. Saito H, Miura K (1963) Preparation of transforming deoxyribonucleic acid by phenol treatment. Biochim Biophys Acta 72:619-629

26. Saitou N, Nei M (1987) The neighboring-joining method: A new method for reconstructing phylogenetic trees. Mol Biol Evol 4:406-425

27. Sasser M (1990) Identification of Bacteria by Gas Chromatography of Cellular Fatty Acids. MIDI Technical note 101. MIDI Inc., Newark

28. Sheu SY, Arun AB, Jiang SR, Young CC, Chen WM (2011) Allobacillus halotolerans gen. nov., sp. nov. isolated from shrimp paste. Int J Syst Evol Microbiol 61:1023-1027

29. Sorokin D. Yu (2005) Is there a limit for high-pH life? Int J Syst Evol Microbiol 55:1405-1406

30. Spring S, Ludwig W, Marquez MC, Ventosa A, Schleifer KH (1996) Halobacillus gen. nov., with description of Halobacillus litoralis sp. nov. And Halobacillus trueperi sp. nov., and transfer of Sporosarcina halophila to Halobacillus halophila comb. nov. Int J Syst Bacteriol 46:492-496

31. Tamura K, Stecher G, Peterson D, Filipski A, Kumar S (2013) MEGA 6: molecular evolutionary genetics analysis 6.0. Mol Biol Evol 30:2725-2729

32. Tanasupawat S, Komagata, K (2001) Lactic acid bacteria in fermented foods in Southeast Asia. In: Nga BH, Tan HM, Suzuki K. (eds) Microbial Diversity in Asia. Technology and Prospects, Singapore: World Scientific Publishing. pp. 43-59

33. Tanasupawat S, Chamroensaksri N, Kudo T, Itoh T (2010) Identification of moderately halophilic bacteria from Thai fermented fish (pla-ra) and proposal of Virgibacillus siamensissp. nov. J. Gen. Appl. Microbiol 56:369-379

34. Tanasupawat S, Namwong S, Kudo T, Itoh T (2007) Piscibacillus salipiscarius gen. nov., sp. nov., a moderately halophilic bacterium from fermented fish (pla-ra) in Thailand. Int J Syst Evol Microbiol 57:1413-1417

35. Tanizawa Y, Fujisawa T, Nakamura Y (2018) DFAST: a flexible prokaryotic genome annotation pipeline for faster genome publication. Bioinformatics 34:1037-1039 
36. Thompson JD, Higgins DG, Gibson TJ (1997) The CLUSTAL_X windows interface: Flexible strategies for multiple sequence alignment aided by quality analysis tools. Nucleic Acids Res 25:4876-4882

37. Thornley MJ (1960) The differentiation of Pseudomonas from other Gram-negative bacteria on the basis of arginine metabolism. J Appl Bacteriol 23:37-52

38. Ventosa A, Garcı'a MT, Kamekura M, Onishi H, Ruiz Berraquero M (1989) Bacillus halophilus sp. nov., a moderately halophilic Bacillus species. Syst Appl Microbiol 12:162-165

39. Wainø M, Tindall BJ, Schumann P, Ingvorsen K (1999) Gracilibacillus gen. nov., with description of Gracilibacillus halotolerants gen. nov., sp. nov.; transfer of Bacillus dipsosauri to Gracilibacillus dipsosauri comb. nov., and Bacillus salexigens to the genus Salibacillus gen. nov., as Salibacillus salexigens comb. nov. Int J Syst Bacteriol 49:821-831

40. Wayne LG, Brenner DJ, Colwell RR, Grimont PAD, Kandler O, Krichevsky MI, Moore LH, Moore WEC, Murray RGE, Stackebrandt E, Starr MP, Trüper HG (1987) Report of the ad hoc committee on their conciliation of approaches to bacterial systematics. Int J Syst Bacteriol 37, 463-464

41. Yoon JH, Kang KH, Park YH (2002) Lentibacillus salicampi gen. nov., sp. nov., a moderately halophilic bacterium isolated from a salt field in Korea. Int J Syst Evol Microbiol 52:2043-2048

\section{Figures}

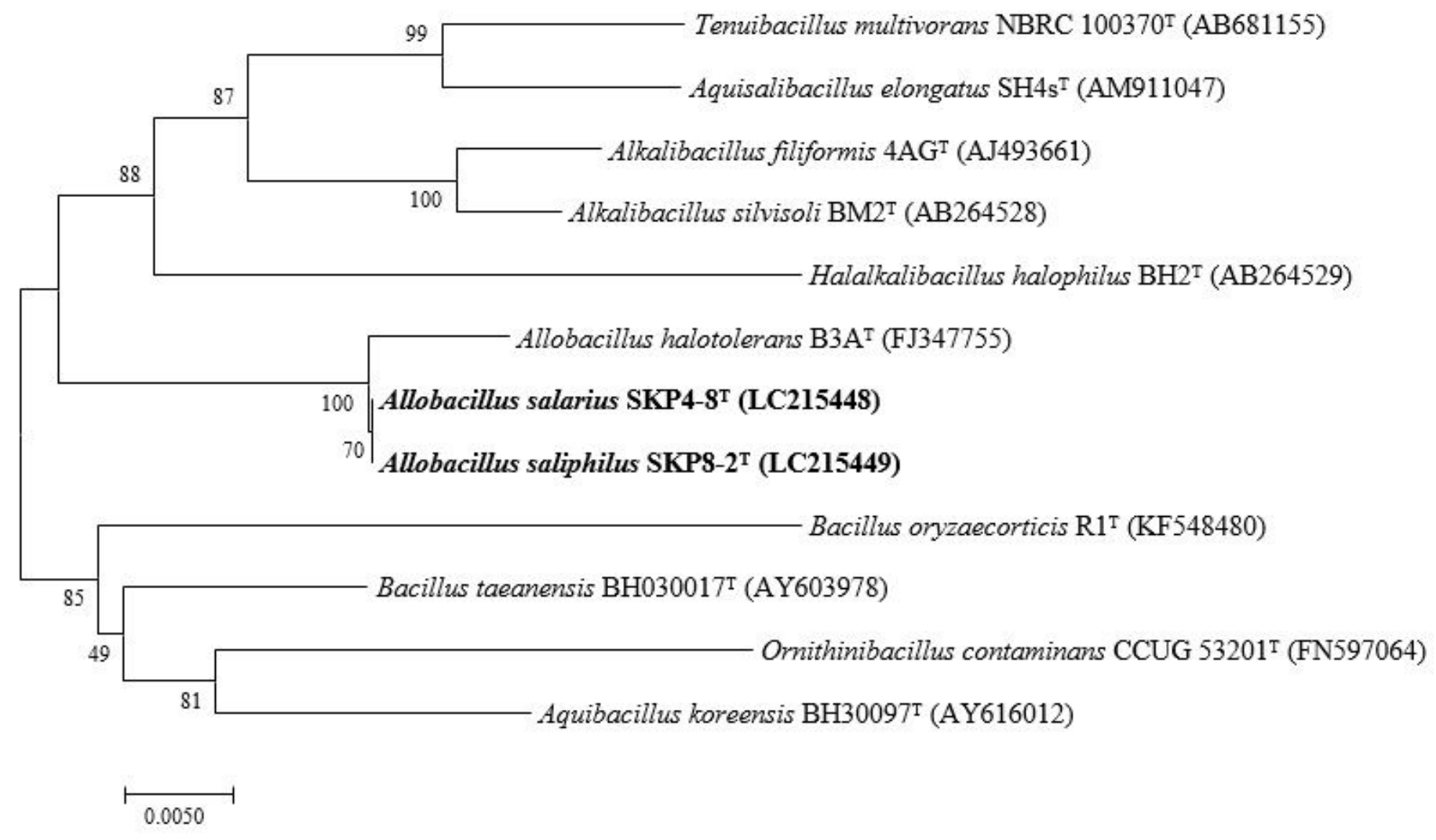

Figure 1 
Neighbor-Joining tree based on 16S rRNA gene sequences showing the relationships between strains SKP4-8T, SKP8-2Tand Alkalibacillus halotolerans LMG 24826T. Bootstrap values (>50\%) based on 1000 replications are given at branch nodes. Bacillus subtilis DSM 10T was used as an outgroup. Bar, 0.005 substitutions per nucleotide position.

\section{Supplementary Files}

This is a list of supplementary files associated with this preprint. Click to download.

- SuppIAllobacillus2novPK.docx 